Annals of Warsaw University of Life Sciences - SGGW

Horticulture and Landscape Architecture No 39, 2018: 83-93

(Ann. Warsaw Univ. of Life Sci. - SGGW, Horticult. Landsc. Architect. 39, 2018)

DOI 10.22630/AHLA.2018.39.8

\title{
The influence of sacral buildings on spatial structure and landscape identity
}

\author{
MAŁGORZATA KACZYŃSKA
}

Faculty of Horticulture, Biotechnology and Landscape Architecture, Warsaw University of Life Science - SGGW

\begin{abstract}
The influence of sacral buildings on spatial structure and landscape identity. The subject of the article is the urban cultural landscape and the influence of the Christian religion (Roman Catholic Church) on the landscape. The research was aimed to determine the influence of the sacral buildings on the southern Warsaw landscape spatial structure and identity. The research consists of an analysis of the period, and circumstances of parishes establishment, and the delimitation of their borders and church location selection, determination of the parishes landscape composition and spatial structure. The research showed that the sacral architectural influence on the landscape's spatial structure and identity is still visible.
\end{abstract}

Key words: sacred landscape, Warsaw, perceptional analysis, church, landscape dominant, urban cultural landscape

\section{INTRODUCTION}

The subject of the article is the influence of the Roman-Catholic Church on the urban landscape. For over a thousand years Poland has remained under the influence of Western-European civilization, the foundations of which were created by Christianity. Today, the influence of the Christian religion and sacral architecture on the landscape and its identity is still visible. Plit (2008) indicates that there is an impact of civilization's religion on the form of landscape it inhabited. According to Plit, the range of occurrences of sacral buildings can be a basis for the delimitation of landscapes shaped by the Latin (Western-European) civilization, the Orthodox (Eastern-European) civilization and the Muslim civilization. Dąbrowska-Budziło (2013) argues that religion is a source of substance which underlies human actions and is expressed in the landscape. In literature there are two terms characterizing the type of cultural landscape where sacral and religious values are important. The first one is the sacral landscape which is related to a material manifestation of the sacred such as the presence of places of worship. Lehmann (1970) considers the sacral landscape as the spiritual and cultural heritage, expressed in sacral buildings in the landscape. According to Jackowski (2003), the sacral landscape is created by sacral buildings established in a particular time on a particular area. Research on the sacral landscape focuses on the landscape's transformation under the influence of religious function development and interaction between the sacred and surrounding space (Jackowski 2007).

Related to the sacral landscape term is the religious landscape. A lot of researchers consider both terms as synonyms. According to Park (1994), the range of 
research on the religious landscape includes, among others, such issues as: sacral architecture and churches spatial distribution, and dynamics of changes. Myga-Piatek (2012) argues that these two terms should be defined separately. According to her the sacral landscape is identified on the perceptional level of an individual or a community and most frequently remains at an intangible level. The religious landscape often evolves from the initial sacral form and materializes in space through the presence of worship places.

Madurowicz (2002) conducted the research on the sacred realm in urban space. He classified the sacred realm in the urban landscape as the pure sacred realm (temples of different religions and cemeteries), quasi-sacral zones in the profane realm (roadside shrines and crosses, memorials, insurgents' graves, places of citizens' collective execution, monuments), zones of the profane in the sacred realm (inscriptions, monuments, memorials of important past events, which do not have a clearly sacral character, the historical city center) and the border area between the sacred realm and the profane realm.

The subject of the research described in this article, in reference to the presented terms, are churches, which are the material manifestation of the sacred in the urban landscape and are an important part of the pure sacred realm.

According to Lynch (1960), identity is a part of an image of a city. The image of a city is the physical and most instantly perceived reflection on its identity (Kaymaz 2013). Stobbelaar and Pedroli (2011) define landscape identity as a perceived uniqueness of a place, and the uniqueness is based on the interaction between the physical environment and social factors. According to Relph (1976), the identity of a place consists of three interrelated components: physical features and appearances (natural and manmade elements, an environment which offers its own characteristics), activities (events, functional patterns of place) and meaning and symbols (factors shaped through experiences and interactions among the users of a place). Among the physical components, he indicates the manmade elements - like characteristic buildings. The landscape's identity is the sum of the elements which identifies the particular landscape, characteristic features that distinguish it from the others (Stanowicka-Traczyk 2008), all being the reason why a certain society relates to its landscape (Bogdanowski 1983). Important elements of the landscape identity are architectonic objects, especially those which constitute the dominants of the spatial composition, such as unique buildings distinguishing them from their environment. These dominants contribute to the establishment of the notion of "our town", and they become symbols of the town (Wejchert 1984). They are the landscape element which allows citizens to identify with their surroundings. Churches are certainly such distinguishing buildings in the Polish town landscape which often perform the function of a dominant. Sowińska (2012) among the material distinctive features of the sacral landscape identity names: the natural-spatial context (natural, cultural and historical conditions), architectonic form of the worship building, its integrity with the surrounding which influences its visual perception, clarity (clear char- 
acteristics, eye catching special signs) and openness (range of view on the landscape's surrounding sacral buildings and range of a panorama seen from the sacral building situated on a hill).

Sacral buildings are the most important material components of the sacred sphere of the urban landscape. Their dominant role is revealed through their architectonic form, symbolism and location in the landscape and its compositional relations. According to Madurowicz (2002), historically churches were the basis of a whole town's composition. Nadrowski (2008) emphasizes that a church with its facilities and spatial context was an indispensable element of the urban structure and city panorama.

TABLE. List of analysed sacral buildings. Church numbers are compatible with the map showing the area of the examined parishes

\begin{tabular}{|r|l|}
\hline No & Name of sacral building \\
\hline \multicolumn{2}{|l|}{} \\
\hline 1 & $\begin{array}{l}\text { Church of St. Joseph the Betrothed of the Blessed Virgin Mary (St. Stephan the King in Sielce } \\
\text { parish) Sisters of Nazareth convent }\end{array}$ \\
\hline 2 & Church of St. Casmir the Prince in Sielce (Resurrectionist Congregation) \\
\hline 3 & Sanctuary of Our Lady Teacher of Youths (Our Lady Queen of the Believers parish) \\
\hline 4 & $\begin{array}{l}\text { Churches of St. Antonio of Padua and St. John of Dukla (St. Boniface in Czerniaków parish) } \\
\text { Bernadine cloister }\end{array}$ \\
\hline 5 & Church of St. Thaddeus the Apostle \\
\hline 6 & Church of St. Antonio Maria Zaccaria (Barnabite Fathers parish) \\
\hline 7 & Church of St. Anna \\
\hline 8 & Temple of God's Providence \\
\hline 9 & Church of the Mission of the Lord's Disciples \\
\hline \multicolumn{2}{|l|}{ Stużew deanery } \\
\hline 10 & Church of Our Lady Mother of Mercy (congregation of Marianist Brothers and Priests parish) \\
\hline 11 & Church of St. Maximilian Kolbe \\
\hline 12 & Church of St. Dominique and Dominican cloister \\
\hline 13 & Church of the Immaculate Conception of the Virgin Mary (St. Catherine parish) \\
\hline 14 & Church of St. Madeleine Sophie Barat, Sacred Heart of Jesus convent \\
\hline 15 & Church of SS Peter and Paul the Apostles \\
\hline \multicolumn{2}{|l}{ Ursynów deanery } \\
\hline 16 & Church of the Lord's Ascension \\
\hline 17 & Church of the Blessed Edmund Bojanowski \\
\hline 18 & Church of St. Thomas the Apostle \\
\hline 19 & Lord's Offertory church \\
\hline 20 & Church of the Blessed Ladislas of Gielniow \\
\hline 21 & Church of St. Pio of Pietrelcina \\
\hline 22 & Sanctuary of Our Lady Longing (St. Elisabeth parish) \\
\hline
\end{tabular}


The church was a dominant element of a medieval city and an important element of the urban space aesthetics in the renaissance. In the baroque period and in the 19th century, churches were located at a closure of the compositional axis, on large squares. In the 20th century, churches became part of housing estates. In Poland during the communistic period, sacral buildings were often neglected in new designs of housing districts. After 1989, when free land trade became possible, the approach towards the church's location was changed. Sacral buildings were often located in areas originally destined for other purposes because of the necessity for increasing the worship places number (Klima 2011).

\section{MATERIAL AND METHODS}

The aim of the research was to identify the influence of the parish complexes (22 Roman-Catholic parishes from 3 deaneries) on the spatial structure and identity of the southern Warsaw landscape. The southern Warsaw urban landscape was shaped mostly from the 1970s to the 1990 s and at the start of the $21 \mathrm{st}$ century. Its spatial composition is based on the historical road system of the previously existing rural area. Although a great part of the landscape is occupied by relatively new housing estates, the spatial complexes of former villages, with their internal road system, are still preserved. The analysed area reflects a process of city development through the incorporation of the rural area with existing historical parish churches into the city boundaries and the establishment of new urban housing estates with new parish churches meeting the needs of new communities (Kaczyńska and Sikora 2015). Therefore, the selected case study provides an opportunity to analyse churches of different times of origin and different architectural forms.

The research included the analysis of the time and circumstances of the establishing of parishes, their coverage transformation and the choosing of the parochial church location. The analysis was based on literature review and historical cartographical materials studies.

\section{RESULTS}

The area of research is the part of the southern Mazovia region which initially was a part of the Poznań diocese and in 1798 became a part of the newly established Warsaw diocese. The earliest parishes erected in the southern Mazovia region are St. Catherine parish in Służew, erected in 1238, St. Nicolas and St. Anna parish in Milanów (later Wilanów), erected in the middle of the 13 th century to the east of Służew, and St. Elisabeth parish in Powsin erected in 1410 as a result of the division of the parish in Milanów. Till the 19th century the parish structure organization in this area had not been changed.

The presently existing parish churches were built in a later period (St. Catherine church at the turn of the 15 th century, St. Nicolas and St. Anna church in 1772, St. Elisabeth church in 1725) and they have replaced previously existing buildings.

A part of the parishes were erected next to the already existing cloisters and cloister churches. The first one, St. Boni- 


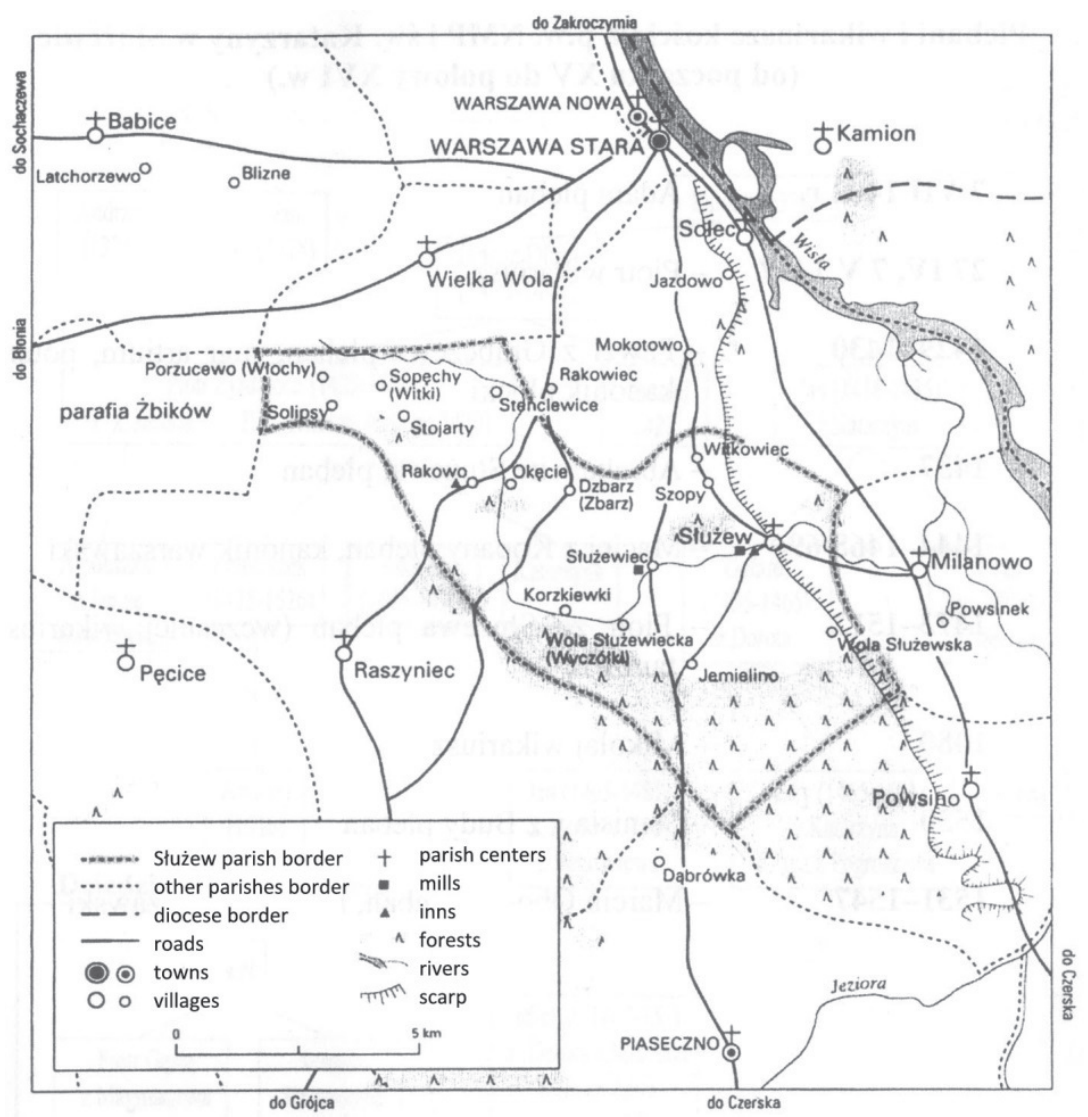

FIGURE 1. Limits of the southern Warsaw parishes at the end of the 15th century (Piber 2001)

face parish in Czerniaków was established at the beginning of the 20th century next to St. Anthony of Padua church and the Bernardines' cloister built in 1690-1693, founded by the Polish magnate Stanisław Herakliusz Lubomirski. In 1950, a part of St. Boniface parish terrain became the St. Casmir parish in Sielce, erected next to St. Casmir the Prince church built in 1932-1933 by Resurrectionist Order. In 1952 from the division of St. Catherine parish in Służew, St. Dominic parish was established. The parishioners used the church built by the Dominicans in 1935 (the presently existing church was built in 1981-1994). In 1973 St. Stephan the King parish in Sielce was established, next to St. Joseph the Betrothed to the Virgin Mary church built in 1926 by Sisters of Nazareth convent. In 1946 the SS Peter and Paul the Apostles parish in Pyry was erected, which resulted from the division of St. Catherine parish in Służew. In 1950, next to the existing wooden chapel, St. Thaddeus the Apostle parish in Sadyba was created which was separated from St. Boniface parish in Czerniaków. In 1952 St. Madeleine Sophie Barat parish in Grabów was established next to a chapel erected on ter- 
rain bought by the Sacred Heart of Jesus convent just before World War II.

Other parishes, such as the parish of Our Lady the Mother of Mercy in Stegny (congregation of Marianist Brothers and Priests), the Our Lady Queen of the Believers parish in Siekierki, St. Maximilian Kolbe parish in Służewiec, Lord's Ascension parish in Stokłosy, St. Thomas the Apostle in Imielin, Lord's Offertory in Wyżyny and the Blessed Ladislas of Gielniow in Natolin were erected in the 1980s. After the collapse of the Polish People's Republic, other parishes were established: in 1995 St. Antonio Maria Zaccaria parish in Stegny (Barnabite Fathers) which was created from a part of the territories of three previously existing parishes - Our Lady the Mother of Mercy parish, St. Thaddeus the Apostle parish and St. Nicolas and St. Anna parish. In 1999 the parish of St. Pio of Pietrelcina in Moczydło was erected and in 2001 the Blessed Edmund Bojanowski parish in Wolica was created. The last parishes created within the research area were the parish of God's Providence in Wilanów and the parish dedicated to Mission of the Lord's Disciples in Kępa Zawadowska.

The oldest churches were built by orders (e.g. the church in Służew founded by the Order of the canons regular in Czerwińsk) or landowners who erected churches not only as a votive offering but also to provide easier access to religious services for their subjects (e.g. the church in Powsin, erected by the Ciołek family, the church in Wilanów founded by the successors of the then Milanów manorial estate, the church and cloister in Czerniaków founded by Stanisław Herakliusz Lubomirski).
The majority of the parish complexes was established on the newly constructed housing estates - the last ones on the territories most recently incorporated into the city area, where a housing development process has just begun.

The first settlements were built on the postglacial plain escarpment along the edge of the fluvial terrace of the Vistula river valley, along streams, small natural lakes and ponds. The oldest settlements in the region, such as Służew and Milanów, were established in such a location. The historical churches were usually located in the center of the settlement, often on the highest place (e.g. the church in Służew) or close to the residence of the landowner who founded the temple (e.g. the church in Wilanów). Parishes included from a few up to a dozen villages and were related to the landownership. The church had to be easy accessible for all parishioners. For instance, the church in Powsin was erected in 1398 for the inhabitants of the Ciołek family manorial estate who previously had to go to churches in other villages such as Milanów or Służew. Further parishes were created through the division of those previously erected. The aim was the reduction of the distance between the church and surrounding villages and settlements. A part of the oldest parish in Służew became the parish in Milanów (later Wilanów), and in 1410 a part of those parishes' territories became the parish in Powsin (Karaszewski 2011). To trace the parishes limits also natural barriers were taken into consideration. A great part of the original boundary between the parish in Stużew and the parish in Milanów was established along the postglacial plain escarpment and marsh- 


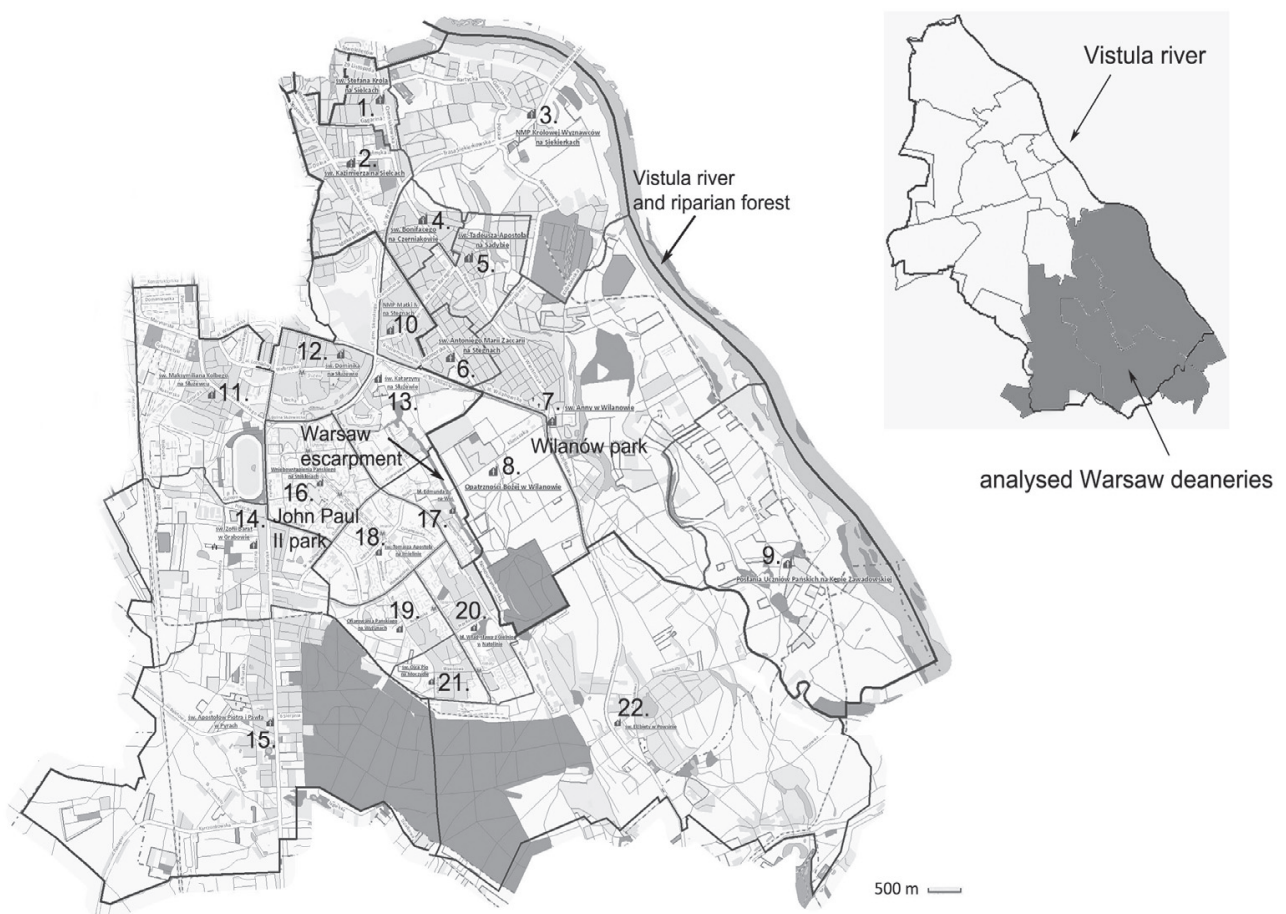

FIGURE 2. Map showing the area of the examined parishes (the numbers from 1 to 22 mark parish churches). Based on maps of Warsaw deaneries available on website http://koscioly.warszawa.pl

es and woods located beneath it which constituted the natural barrier. When the new church in Powsin was built, the boundary between the newly established parish and the existing parish in Służew was set along the area of the dense forest which was a natural obstacle (Piber 2001). Sometimes even the area which administratively constituted one settlement or village was divided into two different parishes because of the existing natural topographical barriers. For instance Okrzeszyn village, set along two sides of the Wilanówka river, belonged to two parishes.

Presently, also new parishes are created through the division of those previously existing to facilitate access to a church (e.g. the largest parish of Lord's
Ascension in Stokłosy is a part of the existing St. Madeleine Sophie Barat parish in Grabów, while St. Thomas the Apostle in Imielin is a part of the existing parish in Służew). The number of parishes depends rather on the urban development than the administrative area. The building of new churches is related to residential areas development. The church location depends on functional reasons - easy access for the parishioners. For example, the newly built church in Kępa Zawadowska was located in the parish center, which provides comfortable access for all parishioners although presently the church's nearest surrounding is less inhabited than the northern area of the parish. Also, present parish boundaries are determined on the 


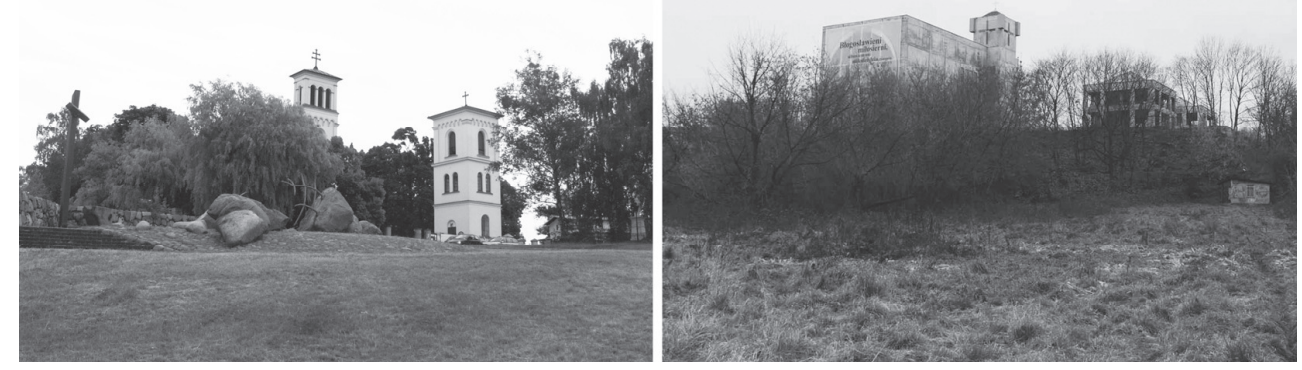

FIGURE 3. St. Catherine church in Służew and the Blessed Edmund Bojanowski church in Wolica
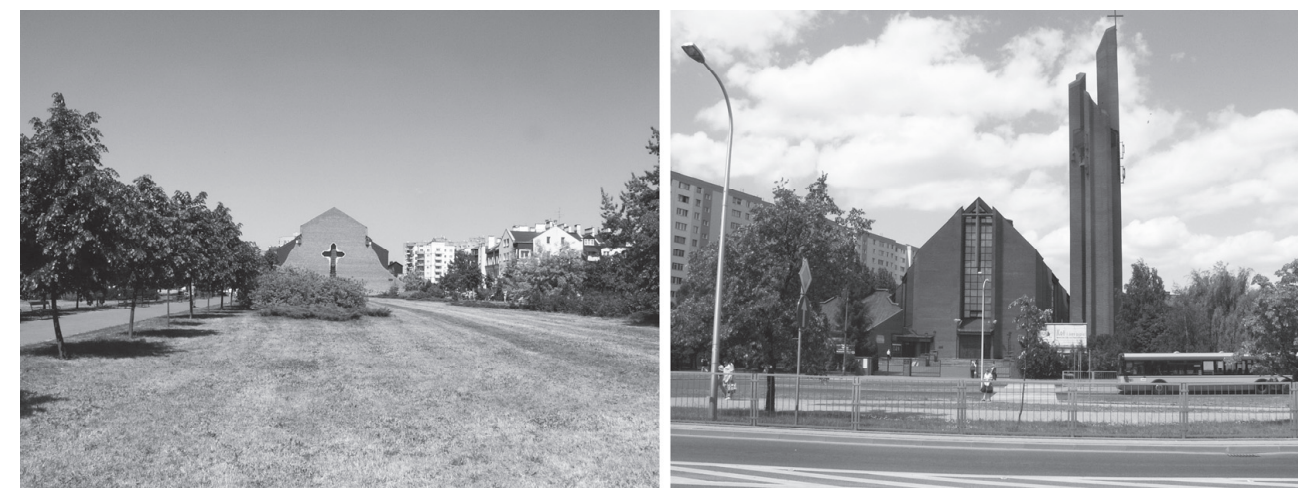

FIGURE 4. Lord's Ascension church in Stokłosy and Our Lady the Mother of Mercy church in Stegny
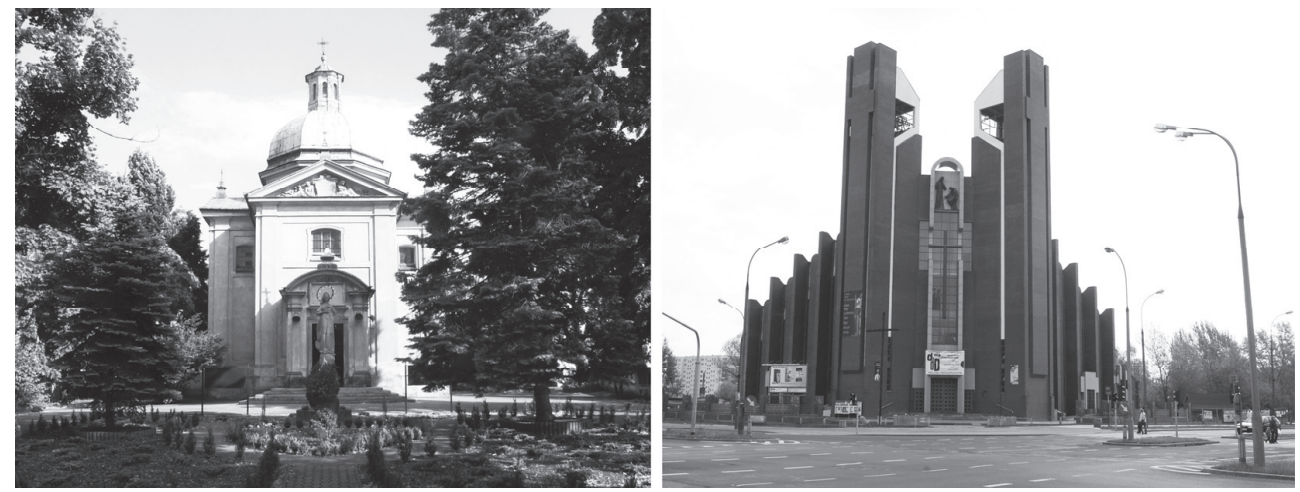

FIGURE 5. St. Anthony of Padua church in Czerniaków and St. Thomas the Apostle church in Imielin 

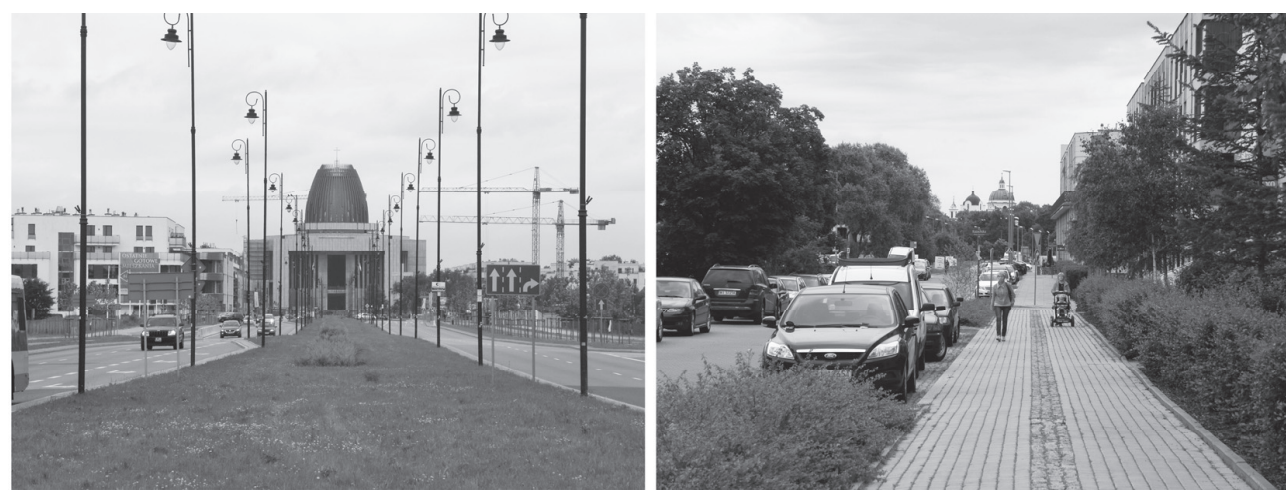

FIGURE 6. Temple of God's Providence and St. Nicolas and St. Anna church in Wilanów

basis of functional reasons. For instance a road leading to one parish cannot cross a neighboring parish. Topographical barriers such as escarpments, valleys, rivers or streams also today are used to set the borderlines between parishes.

The historical churches usually have been located on the highest places, which emphasized their prestige and allowed them to dominate the surrounding landscape. Churches built on a flat terrain were also perceived as landscape dominants because they were usually surrounded by rural residential areas, fields and meadows. Some churches (e.g. the churches in Wilanów and Służew) were visually connected and constituted an important element of a composition of the landowners' residential gardens. Their dominant role in the landscape and compositional relation with other landscape elements have become less visible now because of intense urban development.

During the period of the Polish People's Republic churches were built in less prestigious places, which did not allow them to have visual impact on the surrounding landscape. For example, the former authorities rejected the proposal to build a new church on the top of an escarpment and decided to locate the church of St. Thomas the Apostle in Imielin in the middle of the Southern Ursynów housing estate. New churches, often surrounded by high blocks of flats, seemed to be "pushed into" residential areas and were not perceived as landscape dominants (i.e. the church of Our Lady the Mother of Mercy in Stegny). An exception is Lord's Ascension church in Stokłosy built in the center of a housing estate, on the large square previously occupied by the marketplace, which was transformed into a representative public space. The church unexpectedly has become the dominant of the whole residential area (Klima 2011).

After the political transformation in 1989 , because of the necessity for increasing the number of places of worship, sacral buildings were often located in areas originally destined for other purposes. For example, the church of the Blessed Edmund Bojanowski in Wolica was built on the edge of the escarpment, next to the natural reserve area, because the local authorities could not find another location for the sacral building in this neighbourhood. 


\section{SUMMARY}

Churches, with their landscape, historical and cultural context, are the material expression of landscape identity. Sacral buildings decide about an image of a city and because of their distinguished form they are often perceived as architectonic dominants. Churches perform a role of landmarks - point references which facilitate orientation within the city.

The research has shown that the parish organizational spatial structure resulted from functional reasons (church distance), landscape conditions (taking into consideration natural terrain barriers like rivers, streams, escarpments etc.) and the administrational structure (taking into consideration the city's borders in the parish structure). Taking into consideration in the contemporary spatial parish structure the natural landscape conditions proves respect for important elements of the identity of the city, such as the landscape's physiognomy and topographical features.

The contemporary churches are built in locations which are most adequate because of the functional reasons, not because of their special topographical and landscape values. However, all churches, both the historical and the new ones, are situated along the main streets which are usually parallel to the linear topographical elements of the Vistula river valley. The churches, with natural landscape features, create a clear spatial structure.

\section{REFERENCES}

BOGDANOWSKI J. 1983: Wprowadzenie do regionalizmu architektoniczno-krajobrazowego. Wiad. Ekol. 29: 183-197.
DĄBROWSKA-BUDZIŁO K. 2013: Forma i treść krajobrazowej kompozycji. Wydawnictwo Politechniki Krakowskiej, Kraków.

JACKOWSKI A. 2003: Święta przestrzeń świata. Podstawy geografii religii. Wydawnictwo Uniwersytetu Jagiellońskiego, Kraków.

JACKOWSKI A. 2007: Rozważania o krajobrazie sakralnym. In: K. Ostaszewska, I. Szumacher, S. Kulczyk, E. Malinowska (Eds.) Znaczenie badań krajobrazowych dla zrównoważonego rozwoju. Wydawnictwo Uniwersytetu Warszawskiego, Warszawa:133-143.

KACZYŃSKA M., SIKORA D. 2015: The church garden as an element shaping the quality of city life - a case study in southern Warsaw. Ann. Warsaw Uni. of Life Sci. - SGGW. Horticult. Landsc. Archit. 36: 71-92.

KAYMAZ I. 2013: Urban Landscapes and Identity. In: M. Ozyavuz (Ed.) Advances in Landscape Architecture. InTech: 739-760.

KARASZEWSKI Z. 2011: W cieniu stolicy. Ks. Paweł Bijak List do Parafian 7: $15-18$

KLIMA E. 2011: Przestrzeń religijna miasta. Wydawnictwo Uniwersytetu Łódzkiego, Łódź.

LEHMANN M. 1970: Die Kalvarienberganlagen im Donauraum. In: W. Flieder (Ed.) Festschrift Franz Loidl zum 65. Geburtstag. Sammlung "Aus Christentum und Kultur" Sonderband 1, Wien: 113-159.

LYNCH K. 1960: The Image of the City. The Technology Press and Harvard University Press, Cambridge.

MADUROWICZ M. 2002: Sfera sacrum w przestrzeni miejskiej Warszawy. Wydawnictwo Akademickie Dialog, Warszawa.

MYGA-PIĄTEK U. 2012: Krajobrazy sakralne i religijne - próba umiejscowienia w typologii krajobrazów kulturowych. Pr. Kom. Kraj. Kult. 17: 13-23.

NADROWSKI H. 2008: Bliższe i dalsze otoczenie kościoła. In: R. Kozakiewicz- 
-Opałka, G. Zarzycki, B. Zapała (Eds.) Ogród sakralny - idea i rzeczywistość: VII Międzynarodowa Konferencja o Architekturze i Sztuce Sakralnej z cyklu "Kościoły naszych czasów", Kielce - SacroExpo 2008. Stowarzyszenie Architektów Polskich, Oddział Kielce, Kielce: 51-70.

PARK Ch.C. 1994: Sacred Worlds: An Introduction to Geography and Religion. Routledge, London.

PIBER M. 2001: Służew średniowieczny. Dzieje parafii i wsi Służew w ziemi warszawskiej. Towarzystwo Naukowe Warszawskie, Warszawa.

PLIT F. 2008: The determinants of the landscape of Europe civilization. Dissertation of Commission of Cultural Landscape PGS 8: 92-104.

RELPH E. 1976: Place and placelessness. Pion, London.

SOWIŃSKA B. 2012: Kształtowanie tożsamości krajobrazów sakralnych. Pr. Kom. Kraj. Kult. 17: 78-95.

STANOWICKA-TRACZYK A. 2008: Kształtowanie wizerunku miasta na przykładzie miast polskich. Oficyna Wydawnicza Branta, Bydgoszcz-Olsztyn.

STOBBELAAR D.J., PEDROLI B. 2011: Perspectives on landscape identity: a conceptual challenge. Landsc. Res. 36 (3): 321-339.

WEJCHERT K. 1984: Elementy kompozycji urbanistycznej. Arkady, Warszawa.
Streszczenie: Wplyw budowli sakralnych na strukture przestrzenna i tożsamość krajobrazu. Przedmiotem rozważań artykułu jest krajobraz kulturowy miasta oraz wpływ religii chrześcijańskiej (Kościoła rzymskokatolickiego) na ten krajobraz. Celem badań było określenie wpływu obiektów sakralnych na strukturę przestrzenną i tożsamość krajobrazu południowej Warszawy. Badania obejmowały analizę okresu, okoliczności powstania i zasiegu parafii oraz wyboru lokalizacji kościołów, określenie układu krajobrazowego i struktury przestrzennej parafii. Badania pokazały, że wpływ architektury sakralnej na strukturę przestrzenną i tożsamość krajobrazu jest nadal czytelny.

Slowa kluczowe: krajobraz sakralny, Warszawa, analiza percepcyjna, kościól, dominanta krajobrazowa, miejski krajobraz kulturowy

MS received: 19.02 .2018

MS accepted: 09.07.2018

\section{Author's address:}

Małgorzata Kaczyńska

Katedra Sztuki Krajobrazu

Wydział Ogrodnictwa, Biotechnologii

i Architektury Krajobrazu

Szkoła Główna Gospodarstwa Wiejskiego

w Warszawie

ul. Nowoursynowska 166, 02-787 Warszawa

e-mail: malgorzata_kaczynska@sggw.pl 